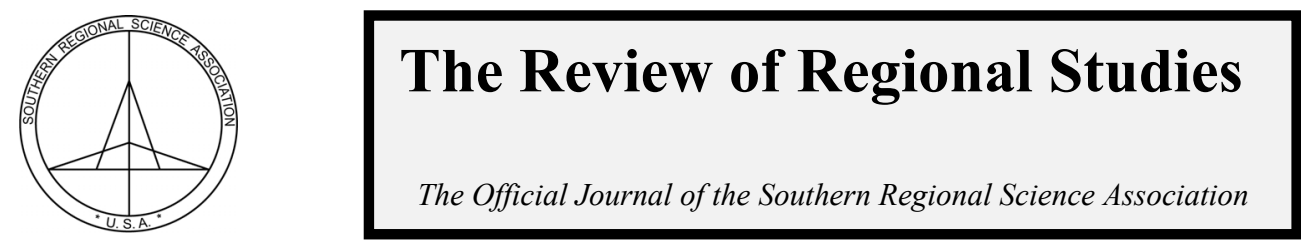

\title{
Pork-Barrel Spending and State Employment Levels: Do Targeted National Expenditures Increase State Employment in the Long Run?
}

\author{
J. Zachary Klingensmith ${ }^{\mathrm{a}}$ \\ ${ }^{a}$ School of Science, Penn State Erie, The Behrend College, USA
}

\begin{abstract}
Pork-barrel spending is defined as a project that is funded by the national tax base and yet only benefits a small, localized population. Anecdotally, this type of spending is often criticized as short-sighted, inefficient, and wasteful. This paper is designed to determine whether pork-barrel spending is a driver of state economic growth, both state employment and gross domestic product, despite criticism to the contrary. I find that pork-barrel spending does have an effect on employment, but this effect is temporary.
\end{abstract}

Keywords: pork-barrel spending, employment

JEL Codes: J21, D72, H50

\section{INTRODUCTION}

Pork-barrel projects have been a major source of political controversy over the past two decades because they are funded with national tax revenues yet only benefit a small, localized population. At the federal level, this occurs when a legislator is able to finance a project in his or her district - a bridge, highway, or park - with tax revenue collected from the entire country. Anecdotally, many pundits see pork-barrel projects as wasteful; but, this is not necessarily true. Rather, many of these projects have a narrow geographical benefit that generates criticism from those that do not receive any direct benefit. Generally, it is believed that legislators pursue this funding in order to bolster their chances at re-election. ${ }^{1}$

There are several ways that pork-barrel spending can advantage incumbents. First, as local voters benefit from such projects, they might be more inclined to vote for the incumbents who obtained the funds. Second, insofar as the projects benefit organized groups, such groups are likely to contribute to the re-election campaigns of incumbents; this also improves the likelihood of reelection. A third possible channel is through the economic effects of the spending itself, which could conceivably enhance local employment. The construction and maintenance of projects require labor, capital, etc. Jobs are thus both directly and indirectly created. Some persons are directly employed through the project and subsequent purchases by all input providers create additional new jobs. ${ }^{2}$ Those whose income has increased through pork barrel projects are also

\footnotetext{
Klingensmith is on the faculty of the School of Science, Penn State Erie, Erie, PA. E-mail: jzk17@psu.edu

${ }^{1}$ Stratmann (2013) summarizes the available literature. While there are several papers establishing a theoretical foundation for using pork-barrel spending to enhance the likelihood of re-election, very few studies exist that find an empirical link.

${ }^{2}$ There is a substantial literature that suggests incumbents are helped by local pork-barrel spending. Even if elected officials genuinely care about their constituents, they still need to focus on being reelected in order to remain in office and continue to cater to the needs of their constituents. (Bickers and Stein, 1996; Ferejohn and Krehbiel, 1987; Inman, 1988; Keefer and Khemani, 2009;
} 
likely to support candidates at the voting booth and through campaign contributions. This paper examines the effects of pork-barrel spending on job creation in both the short and long term.

One major focus of research in labor economics is determining the factors that contribute to increases in employment. This type of research has been conducted at both the national and subnational levels. In general, the results suggest that both economic and public policies matter (Nickell, 1997; Nickell and Layard, 1999; Sanchez, 1999). Political jurisdictions compete with each other for residents and a larger tax base using a combination of fiscal packages (tax and expenditure combinations). Among the more important expenditures are those on education and infrastructure (Blundell, Dearden, Meghir, and Sianesi, 1999; Munnell, 1992; Schultz, 1961). Other relevant variables are beyond the control of local and national governments, such as natural resource endowments and climate. While some literature has considered the role of government policy on employment, thus far it has neglected the extent to which targeted projects affect local employment levels and economic growth rates (Bondonio and Engberg, 2000; Hanson, 2009; Saks, 2008).

This paper uses established labor economics models to determine whether or not porkbarrel spending has an impact on state-level employment. The results suggest that pork-barrel spending increases state employment levels, but the increases are not permanent. For every \$1 million spent, total state employment increases by about 900 jobs in the year the funding is secured. However, around 860 jobs are lost the following year. In general, the results suggest that targeted expenditures, such as those associated with the initial funding of "shovel-ready projects," have a substantial, but temporary effect on local employment. This is plausible due to the prominence of construction and construction-related jobs associated with pork-barrel projects. This also suggests that pork-barrel spending might be used for short-term political gains, even though the economic benefits are minimal and given the opportunity cost of the spending. In addition, I find that while there is a correlation between pork-barrel spending and the unemployment rate, a $\$ 1$ million increase in pork-barrel spending leads to a 0.003 percent reduction in the unemployment rate.

In addition to the impact on employment, there are corresponding increases in the state's gross domestic product (GDP). When calculating a state's GDP, federal transfers are subtracted from the state's total. Therefore, the direct impact of federal pork-barrel spending on a state's GDP should be zero as the spending conducted within the state is counteracted by the federal transfer. Any increase in a state's GDP is evidence of an increase in the state's economic activity above and beyond the initial federal transfer of pork-barrel money.

The findings of this analysis suggest that pork-barrel spending may not be an effective strategy for long-term economic growth. First, while there is an initial increase in employment, there is no evidence of a significant permanent employment increase created by pork-barrel spending. In addition, while one-million dollars of pork-barrel spending yields more than onemillion dollars' worth of economic activity, this may not actually indicate economic growth. These two results, coupled with existing literature, suggest that pork-barrel spending is used to pursue political goals, not economic ones. Pork-barrel spending creates benefits for the politicians through an increased likelihood of re-election (Stratmann, 2013). Therefore, even in an absence of long-

Shepsle, Dickson, and Van Houweling, 2002; Shepsle and Weingast, 1981; Weingast, 1979; Weingast, Shepsle, and Johnsen, 1981).

(C) Southern Regional Science Association 2016. 
run economic benefits, pork-barrel spending persists because of the political benefits gained by incumbents.

\section{PUBLIC POLICIES AND STATE EMPLOYMENT}

A top priority for most politicians is re-election. When legislators preside over a district with high levels of unemployment, they tend to have greater difficulty being re-elected (Alt 1985). Therefore, the legislator has an incentive to do everything in his/her power to provide opportunities for employment, especially when job growth is lacking, as jobs mean votes.

One way that legislators can increase employment in their district is through the appropriation of earmarked spending projects. The government can affect state employment through policies that increase government expenditures (Rephann and Isserman, 1994), alter tax levels (Nickell 2004), and that improve the minimum wage (Zavodny, 2000). In general, policies that promote a more business-friendly ${ }^{3}$ environment increase state economic growth (Gwartney and Lawson, 1996; Karabegović, McMahon, and Samida, 2002; Miller et al., 2012; Stansel, 2013).

Other possible policies that legislators can effect include employment subsidies, microcredit organizations, and public works projects. Policies that promote public capital investments also have a positive and significant impact on employment growth (Munnell and Cook, 1990). Tax credits to firms for the creation of new, full-time jobs have also been shown to have a positive and significant impact on employment levels (Neumark, 2013). Nonetheless, the efficiency of such programs are still in question because the taxes and borrowing necessary to fund the programs tend to reduce jobs at the state-level, as do changes in policy that increase regulatory uncertainty (Faulk, 2002). Tax revenue has both direct and indirect burdens that tend to reduce employment (Gramlich, 1987). Thus, spending an additional dollar on one program may increase jobs in the targeted area, but will likely reduce jobs in other areas.

In addition, government programs often compete with each other for funds. Spending a dollar of tax revenue "here" means there is one less dollar available to be spent on other projects and programs "there." With respect to earmarked spending, one additional dollar appropriated for Florida means that there is one less dollar available for the rest of the forty-nine states (and the rest of the world). Also, politicians engaging in demand-side policies are typically more interested in the visibility of the program and not so much with the efficiency or effectiveness of the spending. In fact, the United Nations found that many international demand-side funding programs are riddled with fraud and are typically ineffective and a "waste of money" (United Nations, 2007).

This paper looks specifically at the effects of targeted national expenditures in the United States, more commonly referred to as earmarks or pork-barrel spending. The goal of this paper is to determine the impact of pork-barrel spending on employment. If incumbents can increase employment through pork-barrel spending projects, even if the impacts are not permanent, they may be able to such spending to bolster their political careers, even if there are minimal economic benefits associated with such programs.

\footnotetext{
${ }^{3}$ There can be some ambiguity with the term "business-friendly." Here it refers to policies that make it easier for a firm to operate in a state. These policies could include a reduction in regulations, a reduction in the corporate tax rate, etc. This term does not refer to crony policies that target specific companies or pass along benefits to specific firms.
}

(C) Southern Regional Science Association 2016. 


\section{MODEL, DATA, AND ESTIMATION STRATEGY}

\subsection{Introduction}

I estimate a labor market model based on Glaeser et al. (1992) and Blumenthal, Wolman, and Hill (2009). These predecessor models were developed to examine the factors that drive employment in urban areas and rely upon a broad range of demographic characteristics to estimate Metropolitan Statistical Area (MSA) employment and Gross National Product (GNP). Their results suggest that business environment, natural amenities, and economic age are the main drivers of urban economic performance, all else being equal. They explore how initial values of such economic fundamentals affect the ten-year average growth rates in employment and per capita GNP in large cities. Glaeser et al. (1992) and Blumenthal, Wolman, and Hill (2009) also use a ten-year period to capture the long-run effects of economic fundamentals and public policy on metropolitan employment and economic growth.

The estimation strategy of this paper assumes that the Blumenthal, Wolman, and Hill (2009) approach also applies to state economies; in addition to economic fundamentals, external grants may also have temporary or permanent effects on employment and economic development. Due to the availability of pork-barrel spending data, this study focuses on the 2001 to 2011 period. Because of a recent moratorium on pork-barrel projects, there has been a negligible amount of pork-barrel spending since 2011. I use three different modeling techniques: a panel, a moving average, and a spatial regression approach. I discuss the differences among the three modeling techniques later. They all follow the same general framework. That is, the dependent variable is the change in total employment or the change in the state's gross domestic product (GDP) across a five-year period. The independent variables are proposed determinants of employment growth, including the state demographics, capital stock, and business climate at the start of each five-year period. Essentially, the independent variables are "starting conditions" for change in employment level or GSP.

In addition to the use of models similar to those used in the aforementioned urban studies, the present analysis also tests for the presence of spatial dependencies. This form of analysis should capture spatial spillovers, insofar as employment opportunities generated by earmarked projects may attract workers and firms from neighboring states.

\subsection{Data: Pork-Barrel Spending}

In order to apply the Blumenthal, Wolman, and Hill (2009) approach, data on state demographics, natural amenities, and business climate were collected for all 50 states from 20012007 (all these variables are only collected for the first year of each five-year period). In addition, data on state employment, GDP, and earmarked spending were collected for the 2001-2011 period. Data on pork-barrel spending are taken from the Citizens Against Government Waste (CAGW) dataset. The CAGW dataset is one of the most commonly used datasets on pork-barrel spending, having been used in previous papers such as Boyle and Matheson (2009) and Stratmann (2013). Further, CAGW is one of the oldest groups that track pork-barrel spending dating back to 1995 with robust data collection beginning in 2001.

As mentioned earlier, pork-barrel spending is federal money that is used to fund projects with a geographically concentrated benefit. Some view this form of appropriation as wasteful, especially since many such projects are categorized as "low-need" (Scovel III, 2007). This type of spending allows politicians to fund projects that may be economically inefficient but highly

(c) Southern Regional Science Association 2016. 
visible. The size distribution of pork-barrel spending varies from state-to-state. Figure 1 shows the distribution of pork-barrel appropriations by dollar amount over the entire ten-year period.

The pork-barrel spending variable takes two different forms. The first is the total amount of state earmarked spending appropriated over each five-year period. The second uses a set of annual spending variables for the final year of each time period in addition to the penultimate year of each time period. I focus on the spending in the last two years of the period of interest because this seems to be where most of the effect takes place. These annual expenditures allow tests of the short- versus long-term effects of spending.

Some research has used a pork-barrel appropriation per capita variable as the variable of interest. For instance, Stein and Bickers (1997) examine the role of pork-barrel spending appropriations per capita on the likelihood of re-election. However, I consider the total amount of pork-barrel spending to establish a clear link between the total amount of money brought into the state and the total number of jobs created. Using per capita values does not allow for this type of analysis. $^{4}$

Another concern is that wealthier states may have an easier time appropriating money as wealthier states may have more legislative power. But, as Figure 2 shows, with few exceptions, there is little correlation between pork-barrel appropriation per capita and GDP per capita. ${ }^{5}$

In addition, an election binary variable is used in the five-year models. Since general elections are held every two years, there are either two or three elections in a given five-year period. The binary variable equals one if there are three elections during the five-year period and equals zero if there were only two elections. If there is an electoral bump in employment due to elections, it should be detected in time periods with an "extra" election.

Figure 1: Distribution of Pork-Barrel Appropriations by Amount Appropriated

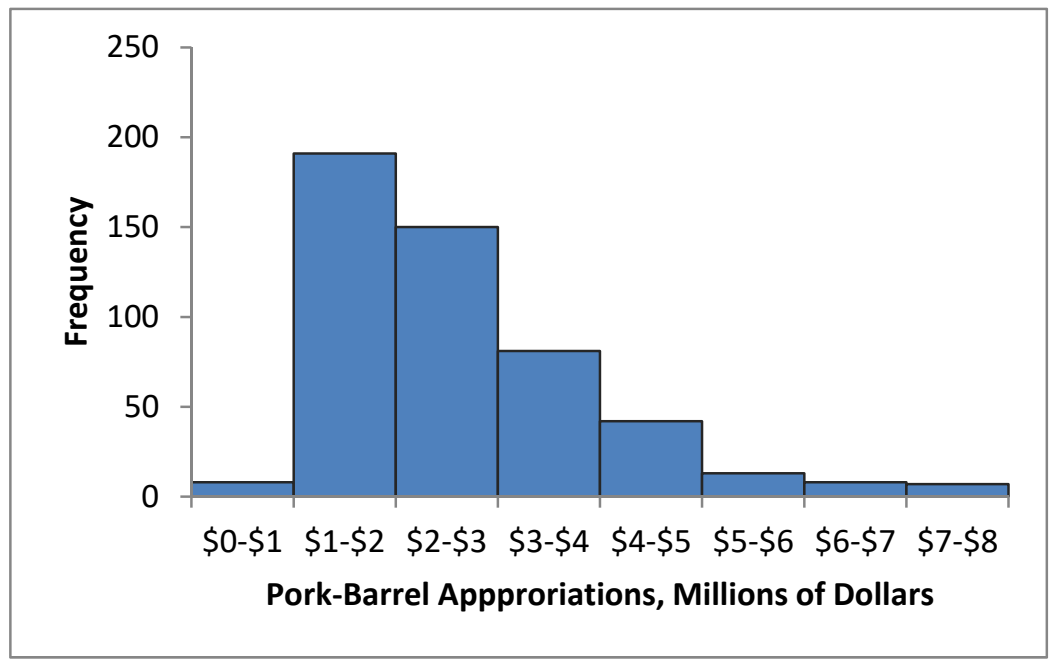

\footnotetext{
${ }^{4}$ When using the pork-barrel spending per capita variable in lieu of total pork-barrel spending for my analysis, the results are ambiguous. This is likely because the cost to create one job should be roughly similar from one state to another (outside of costof-living differences, etc.) but collecting \$1 per capita can vary greatly. For instance, raising \$1 of pork-barrel spending per capita in Wyoming only takes around $\$ 500,000$ worth of appropriations compared to the almost $\$ 40$ million it would take in California. However, it is unlikely that it costs 80 times as much to create a job in California than in Wyoming.

${ }^{5}$ The $R^{2}$ value of the trend line is 0.015 .
}

(c) Southern Regional Science Association 2016. 


\section{Figure 2: Pork-barrel Spending and State Gross Domestic Product}

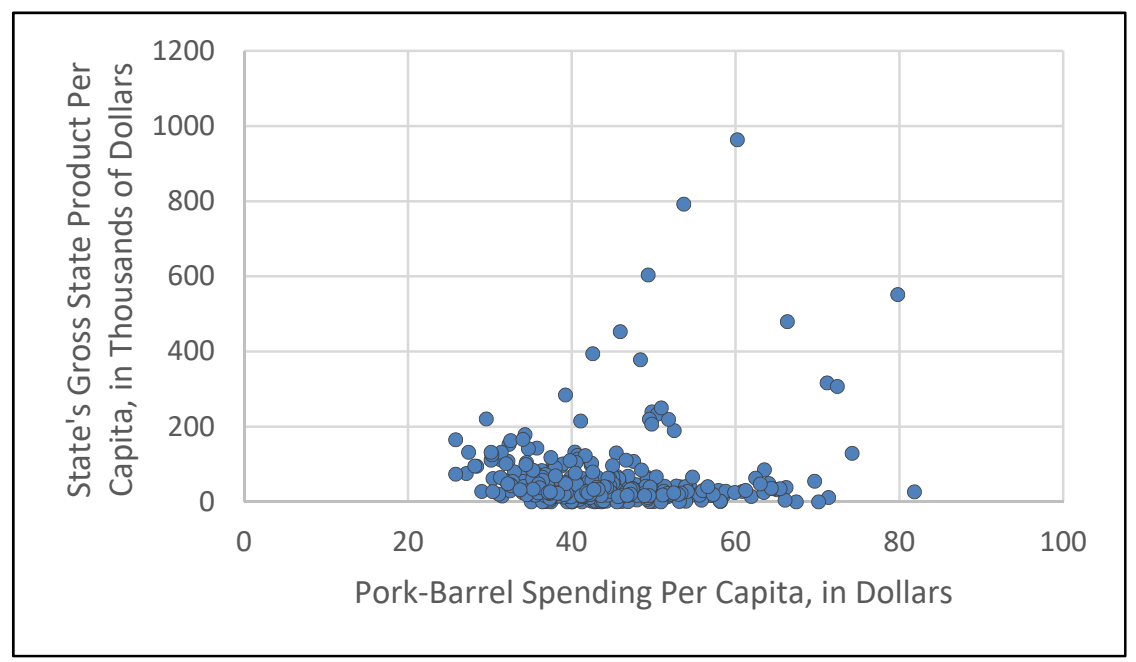

\subsection{Data: Demographic Variables}

The state demographic variables measure the characteristics of state residents in the first year of the period. These include the level of skilled labor, race, and age. These factors have been shown to impact urban labor supplies and employment levels (Levy, et al., 2008; Wolman et al., 2008).

The level of skilled labor affects marginal product and the quality of job opportunities in the present and in the future (Card, 1999). The percentage of adults in a state with a bachelor's degree in the starting year is used as a measure of skilled labor in the state (Blumenthal, Wolman and Hill, 2009). These data are taken from the U.S. Census. A state can take advantage of a workforce with a higher level of education even if the benefits are felt more directly at the metropolitan area level. For instance, the research triangle in North Carolina has not only benefitted the Raleigh-Durham area, but has also benefited the entire state with the overall increase of educated citizens.

The age distribution of a state can also have direct effects on the supply of labor. For example, if a large percentage of the populace belongs to the "dependent population" - that is, children under the age of 18 and adults over the age of 65- the potential labor supply tends to be smaller. Both child labor laws and eligibility requirements for retirement programs exclude most of those populations from the labor force. Although beyond the scope of this paper, a large fraction of dependent persons tends to increase the demand for education and/or healthcare services without producing the tax revenues necessary to support those services. This reduces state funds available for employment promoting expenditures. The percentage of the state's population under 18 in the starting year and the percentage of the state's population aged 65 or older in the starting year is included in the demographic variables each taken from the U.S. Census.

Finally, the percentage of black residents in the state is included to account for two different effects. First, a history of discrimination has led to a strong relationship between the size of the black population in a geographical area and the poverty level (Glaeser and Shapiro, 2001). ${ }^{6}$

\footnotetext{
${ }^{6}$ There are different measures than can be used to measure the impact of poverty such as state median income. The percent of black residents is used to mirror the work of Blumenthal, Wolman, and Hill (2009).
}

(C) Southern Regional Science Association 2016. 
Second, it has been shown that the rate of return for education is greater for the white population (Smith and Welch, 1989), thereby reducing the impact of the black segment of the population within the labor force. When aggregated, the two effects combine to cause a reduction in employment levels, all else equal, as the percent of a population that is black increases.

\subsection{Data: Capital Stock and Business Climate}

In addition to the initial composition of the labor force, the Blumenthal, Wolman, and Hill (2009) results suggest that the preexisting capital stock and location affect prospects for economic development. Two components of the economic structure of a state are used: industry composition and labor costs. The location quotient is one way to measure the industrial composition of an area. The location quotient (LQ) is formally defined as:

$$
\mathrm{LQ}=\frac{\boldsymbol{e}_{\boldsymbol{i}} / \boldsymbol{e}}{E_{\boldsymbol{i}} / \boldsymbol{E}}
$$

where $e_{i}$ is the state-level employment in industry $i, e$ is the total state employment, $E_{i}$ is the national employment in industry $i$ and $E$ is the total employment in the U.S. The LQ allows for a straightforward comparison of the proportion of the state workforce in a given industry against the proportion of the national workforce in the same industry. For instance, $6.08 \%$ of the West Virginia workforce is in the natural resources and mining sector which seems to be relatively small; but, its significance becomes apparent as only $1.80 \%$ of the U.S. workforce is employed in the natural resources and mining sector.

The LQs in the starting year of each employment period for the manufacturing industry (NAICS 31-33) and the finance, insurance, and real estate (FIRE) industry (NAICS 52-53), as classified by the North American Industry Classification System (NAICS), are used to characterize the preexisting capital stock and networks. These data are taken from the Bureau of Labor Statistics. Previous studies have established that an area with a high manufacturing LQ experience higher-than-average job losses due to the decay of the American manufacturing industry (Glaeser et al., 1992; Glaeser, Scheinkman, and Shleifer, 1995; Blumenthal, Wolman, and Hill, 2009). On the other hand, the FIRE sector has experienced growth over the past several decades so there should be a positive relationship between the FIRE LQ and the change in employment (Blumenthal, Wolman, and Hill, 2009). Therefore, it is expected that states with initial higher shares of FIRE employment will experience higher than average employment growth, all else equal. For example, North Dakota is a prime example of a boom-and-bust economy because so much of its industry is focused on natural resources. While the state was doing exceptionally well with the lowest unemployment rate in the country, the recent drop in oil prices has caused problems in the state economy including increases in the unemployment rate, reduction in property values, and concerns about the state's budget due to a reduction in tax receipts. ${ }^{7}$

The average cost of labor in a state is measured with the average annual wage rate. Higher wage rates in one state can cause that state to be less competitive than other similar states. It has been shown that regions with higher relative wage rates will shed employment over time (Henderson, Kuncoro, and Turner, 1995). The average yearly wage rate per job is used and is also obtained from the Bureau of Labor Statistics.

\footnotetext{
${ }^{7}$ See http://www.reuters.com/investigates/special-report/usa-northdakota-bust/ for more information.
}

(C) Southern Regional Science Association 2016. 
Another important measure of a state's capital stock is its connectivity, specifically with regard to highways. The number of miles of interstate highway is used to measure both the transportation capital stock and the degree of physical connectivity in a state.

In addition, a state's business climate is considered. As in Blumenthal, Wolman, and Hill (2009), this paper uses a binary variable indicating whether or not the state is a right-to-work state. Right-to-work' legislation makes it illegal for a firm to require an employee to belong to a union. Twenty-two states have right-to-work laws and are perceived to be more business-friendly (Holmes 1998). States use this type of legislation to encourage firms to either remain in the state or to attract new firms with the promise of lower-priced labor.

Finally, the average July temperature of the state's largest city is used. While this variable may have some weaknesses because only one city is used, the variable still captures the general temperature trend in the state. Essentially, this variable controls for the impact of warmer weather on labor force migration. The descriptive statistics and sources for the data are shown in Table 1.

Table 1: Descriptive Statistics for All Variables

\begin{tabular}{lccccc}
\hline \hline Variable & Source & Mean & St. Dev. & Min & Max \\
\hline $\begin{array}{l}\text { Change in Total Employment, five-year } \\
\text { (thousands of jobs) }\end{array}$ & BLS & 129.25 & 484.76 & $-2,599.4$ & $3,714.6$ \\
$\begin{array}{l}\text { Change in State's Gross Domestic Product } \\
\text { (mil\$) }\end{array}$ & BLS & 43.31 & 62.32 & -29.9 & 419.5 \\
Five-year Aggregate Pork Spending (mil\$) & CAGW & 808.25 & 543.03 & 57.6 & $2,874.73$ \\
$\begin{array}{l}\text { Pork-Barrel Spending in Final Year of } \\
\text { Period (mil\$) }\end{array}$ & CAGW & 159.63 & 134.09 & 0 & 733.63 \\
Pork-Barrel Spending in Penultimate Year & CAGW & 162.48 & 138.06 & 0 & 733.63 \\
of Period (mil\$) & BEA & 0.988 & 0.366 & 0 & 1.81 \\
LQ Manufacturing \# & BEA & 0.963 & 0.194 & 0.63 & 1.79 \\
LQ FIRE \# & Census & 24.99 & 1.96 & 20.5 & 32.1 \\
\% of Population under Age 18 \# & Census & 12.42 & 2.97 & 5.4 & 42.4 \\
\% of Population over Age 65 \# & Census & 10.56 & 11.34 & 0.1 & 76.8 \\
\% of Population who are Black \# & Census & 25.80 & 4.57 & 15.4 & 37.4 \\
\% of Adults with Bachelor's Degree \# & BLS & 35.92 & 5.84 & 25.1 & 54.7 \\
Average Wage (thousands of \$) \# & NRTW & 0.48 & 0.50 & 0 & 1 \\
Right-to-Work State*\# & NOAA & 76.48 & 6.00 & 58.4 & 92.8 \\
Average July Temperature*,\# & FHWA & 604.3 & 373.03 & 0 & 2,041 \\
Number of Miles of Interstate Highway \# & N/A & 0.5 & 0.5 & 0 & 1 \\
Three Elections in Five-Year Period* & Fing
\end{tabular}

Note: Variables marked with an asterisk $\left(^{*}\right)$ are binary variables. Variables marked with a pound sign (\#) indicates that the variable is taken from the first year of the time period used in the model.

\subsection{Estimation Strategy}

Ultimately, while the factors discussed above are important, most studies neglect to consider the impact of directed national expenditures. For example, none of the papers reviewed by Levy et al. (2008) and Wolman et al. (2008) acknowledge the role of directed national expenditures on urban employment. Directed spending is unlikely to have the same type of impact

(C) Southern Regional Science Association 2016. 
as education or infrastructure at the national level, considering the relatively small portion of the federal budget that pork-barrel spending accounts for, but it may affect local employment opportunities. The general structure of the employment regression is as follows:

\section{$\Delta$ Employment over Five Years ${ }_{i}=\beta_{1} \cdot \operatorname{por}_{i t}+\beta_{2} \cdot \operatorname{pork}_{i, t-1}+\beta_{k} \cdot X_{i t}+\varepsilon_{i t}$}

where the dependent variable is the five-year change in employment in state $i$. This equation includes both the current and lagged amount of pork-barrel spending in a state, pork $_{i t}$ and porki,t-1, as control variables. $X_{i t}$ is the set of control variables, $\boldsymbol{\beta}$ is a set of fixed, but unknown coefficients, and $\boldsymbol{\varepsilon}_{i t}$ is the error term. I also examine if state GDP is impacted by pork-barrel spending using the same empirical framework but with state GDP as the dependent variable.

To determine whether such effects exist, three estimations are undertaken. First, the suitability of the Blumenthal, Wolman, and Hill (2009) approach for state employment during the given time period is tested. Next, these models are augmented by including earmarked spending variables using both a panel and moving average approach. These approaches were used to better isolate the impact of the Great Recession. If only a single time period is used, the results have the potential to be biased by the shocks experienced due to the recession. Finally, the estimates are augmented by spatial econometric estimates to account for interstate effects of targeted state expenditures. Specially, I utilize the spatial lag model (SLX). This approach permits me to not only study the impact of the pork-barrel spending appropriated by the state being studied, but also the impact of the pork-barrel appropriations of neighboring states (Vega and Elhorst, 2015). In general, the results suggest that the Blumenthal, Wolman, and Hill (2009) approach can be used to model and estimate state employment levels.

It should be noted that some variables included in Blumenthal, Wolman, and Hill (2009) are not included in this state-level analysis. Some of them, such as the number of airport departures and age of the city, were not included because they are not compatible at the state-level. In addition, I use five-year time periods instead of a single ten-year period in order to use both the panel and moving average approaches. The use of panel and moving average models help reduce the impact the Great Recession has on the variables in this study.

\section{RESULTS AND ANALYSIS}

\subsection{Introduction}

The two dependent variables used in this paper are the change in state total employment and the change in GDP over six five-year time periods. As a robustness check, I consider the change in the unemployment rate. However, changes in the unemployment rate can be misleading. For example, a decrease in the unemployment rate could result from an increase in employment, or it could be the result of a decrease in the size of the labor force due to emigration or retirement. Similarly a rise in the minimum wage can enlarge the labor force and thereby cause unemployment rise to rise. Two hypotheses are tested: first that earmarked federal expenditures affect state employment, and second that the effects are not exclusively realized by the states receiving the targeted expenditures.

\subsection{Panel Estimates of State Employment Effects}

The main disadvantage of the approach used in Blumenthal, Wolman, and Hill (2009) is that there are only enough data to examine one ten-year period. If periods of shorter duration are used, additional econometric techniques can be applied to enable researchers to better control for

(C) Southern Regional Science Association 2016. 
unobservable variables that may bias estimates. Therefore, I use a five-year timeframe, which yields a total of six time periods while still enabling a time period that is long enough to observe long-term effects. As discussed earlier, all of the independent variables, with the exception of the pork-barrel spending variables, are "starting conditions;" that is, the value of each is taken from the first year of each period. For example, for the period that runs from 2001 to 2005 , all of the demographic, capital stock, and business climate variables are from the year 2001. The pork-barrel spending variables are again split into two categories: the first is the aggregate amount of porkbarrel spending over the five-year period while the second is the amount of pork-barrel spending in the final year of the time period as well as the penultimate year of the time period. So, for example, in the time period from 2001 to 2005, the pork-barrel spending from 2004 and 2005 would be used.

Another decision that had to be made was the use of a fixed effects versus a random effects model. When the fixed effects model was utilized, many of the independent variables were excluded as they were picked up by the fixed effects. Further, the Hausman test was inconclusive; therefore, I use a random effects panel approach for this study.

Table 2 presents the results from the random effects estimation. The first column replicates the Blumenthal, Wolman, and Hill (2009) model with state data. In general, the results match those of Blumenthal, Wolman, and Hill (2009). The average wage variable, right-to-work binary variable, and interstate mile variable are all statistically significant and positively correlated with changes in total employment as hypothesized in Blumenthal, Wolman and Hill (2009). The share of the population under the age of 18 variable is statistically significant and negatively correlated with the change in employment. In addition, the percent black variable is negative and statistically significant, which suggests that states with a higher shares of black population have slower employment growth. It should also be noted that the magnitude of the coefficients are different from those in Blumenthal, Wolman, and Hill (2009), but this likely reflects the fact that their analysis was conducted at the metropolitan level, while this study is at the state level.

Column 2 includes the aggregate pork-barrel spending variable as a control variable. While the estimated coefficient is positive, it is not statistically significant at conventional levels. The other independent variables have the same signs as in the previous regression.

What cannot be determined from column 2 is whether or not there are temporary jobs created that disappear over the five-year period. To account for this, annual expenditures during the last two years of each time period are included. The results from column 3 suggest that $\$ 1$ million of pork-barrel spending in the final year of the period increases employment by approximately 900 jobs. However, similar spending from the prior year decreased the number of jobs, suggesting there is a temporary effect of targeted expenditures. In total, after two years, only about 40 jobs of the 900 created remain. After five years, still only approximately 40 jobs remain. Therefore, it is clear that there are jobs created by this type of spending but the impacts are temporary. Further, when the costs of acquiring pork-barrel appropriations are considered, it starts to become clear that the economic benefits of pork-barrel spending are likely overshadowed by the economic costs.

While the long-term benefits are difficult to identity, the short-term effects are surprisingly large. An additional $\$ 1$ million worth of directed expenditures leads to approximately 900 jobs. This amounts to less than $\$ 1,200$ per job created, which seems to support the use of pork-barrel spending, even if the jobs created are only temporary. In theory, politicians bring additional pork- 
barrel spending to their state each year to offset the job losses associated with older pork-barrel projects.

Table 2: Panel (Random Effects) Change in Total Employment, 2001-2011

\begin{tabular}{|c|c|c|c|}
\hline & No Pork & Agg. Pork & Disagg. Pork \\
\hline $\begin{array}{l}\text { Aggregate Pork Spending } \\
\text { (in millions of \$) }\end{array}$ & & $\begin{array}{c}63.178 \\
(61.835)\end{array}$ & \\
\hline $\begin{array}{l}\text { Pork in Final Year } \\
\text { (in millions of } \$ \text { ) }\end{array}$ & & & $\begin{array}{l}905.95 * * * \\
(233.21)\end{array}$ \\
\hline $\begin{array}{l}\text { Pork in Penultimate Year } \\
\text { (in millions of \$) }\end{array}$ & & & $\begin{array}{l}-863.35 * * * \\
(227.86)\end{array}$ \\
\hline LQ Manufacturing & $\begin{array}{l}-58,566 \\
(73,259)\end{array}$ & $\begin{array}{l}-37,719 \\
(76,042)\end{array}$ & $\begin{array}{l}-61,163 \\
(73,019)\end{array}$ \\
\hline LQ FIRE & $\begin{array}{c}-97,077 \\
(157,298)\end{array}$ & $\begin{array}{c}-41,027 \\
(166,579)\end{array}$ & $\begin{array}{c}-74,101 \\
(158,081)\end{array}$ \\
\hline Percent under 18 & $\begin{array}{c}-56,340 * * * \\
(16,325)\end{array}$ & $\begin{array}{c}-60,154 * * * \\
(16,745)\end{array}$ & $\begin{array}{c}-43,681 * * * \\
(16,553)\end{array}$ \\
\hline Percent over 65 & $\begin{array}{c}-4,638 \\
(10,138)\end{array}$ & $\begin{array}{c}-6,748 \\
(10,345)\end{array}$ & $\begin{array}{l}-2,160 \\
(10,021)\end{array}$ \\
\hline Percent Black & $\begin{array}{c}-11,579 * * * \\
(2,572)\end{array}$ & $\begin{array}{c}-9,721 * * * \\
(2,665)\end{array}$ & $\begin{array}{c}-9,189 * * * \\
(2,582)\end{array}$ \\
\hline Percent Bachelor's & $\begin{array}{c}-11,578 \\
(8,772)\end{array}$ & $\begin{array}{l}-9,306 \\
(9,049)\end{array}$ & $\begin{array}{c}-11,070 \\
(8,694)\end{array}$ \\
\hline $\begin{array}{l}\text { Average Wage } \\
\text { (thousands of } \$ \text { ) }\end{array}$ & $\begin{array}{c}44.131 * * * \\
(6.705)\end{array}$ & $\begin{array}{c}41.531 * * * \\
(7.204)\end{array}$ & $\begin{array}{l}41.204 * * * \\
(6.872)\end{array}$ \\
\hline Right to Work & $\begin{array}{c}251,380 * * * \\
(66,627)\end{array}$ & $\begin{array}{c}276,275^{* * *} * \\
(71,091)\end{array}$ & $\begin{array}{c}226,682 * * * \\
(68,529)\end{array}$ \\
\hline Interstate Miles & $\begin{array}{c}324.829 * * * \\
(75.482)\end{array}$ & $\begin{array}{c}296.722 * * * \\
(80.334)\end{array}$ & $\begin{array}{c}308.679 * * * \\
(76.464)\end{array}$ \\
\hline July Temperature & $\begin{array}{c}8,260 \\
(5,203)\end{array}$ & $\begin{array}{l}8,461^{*} \\
(5,206)\end{array}$ & $\begin{array}{l}8,424 * \\
(5,034)\end{array}$ \\
\hline 'Extra' Election & $\begin{array}{c}74,598 \\
(49,930)\end{array}$ & $\begin{array}{c}72,718 \\
(49,960)\end{array}$ & $\begin{array}{c}19,556 \\
(52,312)\end{array}$ \\
\hline Observations & 300 & 300 & 300 \\
\hline Number of Panels & 6 & 6 & 6 \\
\hline$R^{2}$ & 0.256 & 0.259 & 0.310 \\
\hline$\chi^{2}$-Statistic & $99.23 * * *$ & $100.29 * * *$ & $128.35 * * *$ \\
\hline
\end{tabular}

What is neglected in this type of argument is that the benefits of pork-barrel spending at the state level typically do not cover all of the federal costs of the project. In some cases, there is a significant amount of spending that must be matched by state and local governments. In fact, some projects require matching contributions from other agencies in the federal government or private companies. ${ }^{8}$ Essentially, pork-barrel spending can be used to close the funding gap for

${ }^{8}$ http://www.fhwa.dot.gov/ipd/finance/tools_programs/federal_aid/matching_strategies/

(C) Southern Regional Science Association 2016. 
projects. So, even though $\$ 1$ million leads to approximately 900 jobs in the short-term, this does not actually mean that you only need $\$ 1$ million to purchase 900 jobs.

Furthermore, while pork-barrel spending does not appear to have long-term economic benefits, the ability to appropriate a targeted national expenditure may actually allow the politician to spend more money. For instance, the Federal Highway Administration (FHWA) may require a state to come up with $\$ 3$ million for a $\$ 10$ million highway project with the FHWA funding the remainder. But, if the state is able to appropriate $\$ 1$ million through a pork-barrel spending bill, then the local government only needs to come up with $\$ 2$ million. While an increase in government spending may be seen as a negative, politicians are able to spin the arrangement as a "good deal" because they seem to be getting $\$ 10$ million in "local benefits" at a substantial discount (an 80 percent discount in the example above). Commonly referred to as the flypaper effect (Hines and Thaler 1995; Inman 2008), the ability of government spending to attract additional spending is yet another reason politicians are attracted to pork-barrel projects. For instance, Leduc and Wilson (2015) find that state spending on highways was 20 percent greater due to stimulus spending through the American Recovery and Reinvestment Act of 2009. This illustrates the idea that politicians are able to support greater levels of government spending and a potential for employment growth by pointing to the local benefits received compared to the local money spent.

One limitation of this analysis is that I do not examine what types of jobs are created. Put simply, a job is a job, and this paper cannot differentiate between a low-paying temporary job and a high-paying permanent job. Therefore, it is impossible to know if there is an increase in the quality-of-life for the workforce or if what we are seeing is migration of those already employed from one job to another. In order to examine this issue further, I repeat the first three regressions but use the change in the unemployment rate as the dependent variable. The results are presented in Table 3.

The key takeaway from the previous set of regressions is that the amount of pork-barrel spending in the final year of the period is statistically significant and negatively correlated with the unemployment rate, while the pork-barrel spending in the penultimate year of the five-year time periods is statistically significant and positively correlated with the unemployment rate. This closely mirrors the result from the employment regressions as we see a dip in the unemployment rate when pork-barrel funds are appropriated but a subsequent increase in the following year. Furthermore, when looking at the results empirically, a \$1 million increase in pork-barrel spending only reduces the unemployment rate by 0.003 of a percentage point. For a full percentage point reduction in the unemployment rate, approximately $\$ 333$ million of pork-barrel spending would need to be used even though diminishing returns may be present at this level of spending. This is further evidence that pork-barrel spending may have political benefits but has limited economic benefits.

\subsection{Panel Estimates of State Economic Growth Rate Effects}

Next, I repeat the first three regressions, this time using the change in GDP. The results are presented in Table 4. The results in the first column attempt to replicate the Blumenthal, Wolman, and Hill (2009) model. However, several of the independent variables in this regression are no longer significant. In general, the Blumenthal, Wolman, and Hill (2009) approach does not work as well for state GDP growth as it did for employment growth. In column 2, I include the aggregated pork-barrel spending variable, in addition to the other previously used control 
variables. In this case, the aggregated pork-barrel spending variable is both positive and significant which indicates

Table 3: Panel (Random Effects) Change in Unemployment Rate

\begin{tabular}{|c|c|c|c|}
\hline & No Pork & Agg. Pork & Disagg. Pork \\
\hline $\begin{array}{l}\text { Aggregate Pork Spending } \\
\text { (in millions of \$) }\end{array}$ & & $\begin{array}{c}-0.0006^{* *} \\
(0.0003)\end{array}$ & \\
\hline $\begin{array}{l}\text { Pork in Final Year } \\
\text { (in millions of } \$ \text { ) }\end{array}$ & & & $\begin{array}{c}-0.003 * * * \\
(0.001)\end{array}$ \\
\hline $\begin{array}{l}\text { Pork in Penultimate Year } \\
\text { (in millions of } \$ \text { ) }\end{array}$ & & & $\begin{array}{l}0.002 * * \\
(0.001)\end{array}$ \\
\hline LQ Manufacturing & $\begin{array}{l}0.594 * \\
(0.347)\end{array}$ & $\begin{array}{c}0.411 \\
(0.357)\end{array}$ & $\begin{array}{l}0.623^{*} \\
(0.353)\end{array}$ \\
\hline LQ FIRE & $\begin{array}{l}-1.194 * \\
(0.744)\end{array}$ & $\begin{array}{l}-1.668 * * \\
(0.777)\end{array}$ & $\begin{array}{l}-1.034 \\
(0.764)\end{array}$ \\
\hline Percent under 18 & $\begin{array}{c}-0.338 * * * \\
(0.077)\end{array}$ & $\begin{array}{c}-0.300 * * * \\
(0.079)\end{array}$ & $\begin{array}{c}-0.308 * * * \\
(0.080)\end{array}$ \\
\hline Percent over 65 & $\begin{array}{l}-0.023 \\
(0.048)\end{array}$ & $\begin{array}{l}-0.004 \\
(0.049)\end{array}$ & $\begin{array}{l}-0.019 \\
(0.048)\end{array}$ \\
\hline Percent Black & $\begin{array}{l}-0.017 \\
(0.012)\end{array}$ & $\begin{array}{l}-0.010 \\
(0.013)\end{array}$ & $\begin{array}{l}-0.019 \\
(0.012)\end{array}$ \\
\hline Percent Bachelor's & $\begin{array}{c}-0.144 * * * \\
(0.042)\end{array}$ & $\begin{array}{c}-0.165 * * * \\
(0.043)\end{array}$ & $\begin{array}{c}-0.014 * * * \\
(0.024)\end{array}$ \\
\hline $\begin{array}{l}\text { Average Wage } \\
\text { (thousands of } \$ \text { ) }\end{array}$ & $\begin{array}{l}0.0003 * * * \\
(0.00003)\end{array}$ & $\begin{array}{l}0.0003 * * * \\
(0.00003)\end{array}$ & $\begin{array}{l}0.0002 * * * \\
(0.00003)\end{array}$ \\
\hline Right to Work & $\begin{array}{l}1.0499 * * * \\
(0.315)\end{array}$ & $\begin{array}{l}0.805 * * \\
(0.337)\end{array}$ & $\begin{array}{l}1.022 * * * \\
(0.331)\end{array}$ \\
\hline Interstate Miles & $\begin{array}{l}-0.0001 \\
(0.0004)\end{array}$ & $\begin{array}{c}0.0001 \\
(0.0004)\end{array}$ & $\begin{array}{l}-0.0002 \\
(0.0004)\end{array}$ \\
\hline July Temperature & $\begin{array}{l}-0.015 \\
(0.025)\end{array}$ & $\begin{array}{l}-0.017 \\
(0.024)\end{array}$ & $\begin{array}{l}-0.014 \\
(0.024)\end{array}$ \\
\hline 'Extra' Election & $\begin{array}{l}-0.0592 \\
(0.236)\end{array}$ & $\begin{array}{l}-0.078 \\
(0.235)\end{array}$ & $\begin{array}{c}0.236 \\
(0.253)\end{array}$ \\
\hline Observations & 300 & 300 & 300 \\
\hline Number of Panels & 6 & 6 & 6 \\
\hline$R^{2}$ & 0.2713 & 0.2813 & 0.294 \\
\hline$\chi^{2}$-statistic & $107.22 * * *$ & $112.32 * * *$ & $119.04 * * *$ \\
\hline
\end{tabular}

that pork-barrel spending can be used to increase the GDP in the long-run, even though the increase is relatively small. In total, a \$1 million increase in pork-barrel spending leads to an average GDP increase of $\$ 459,000$ million dollars. As mentioned earlier, pork-barrel spending is considered to be a federal subsidy which means that the state spending on pork-barrel projects is negated by the amount of the subsidy. Therefore, a positive coefficient indicates that the state's GDP has increased above and beyond the amount of pork-barrel money appropriated to the state. The 
independent variables that were statistically significant in the previous treatment, such as the location quotient for the FIRE industries, the percentage of the population over 65 years old and the average wage, maintain their expected relationship and statistical significance.

Table 4: Panel Estimates for Change in State's Gross Domestic Product, 2001-2011

\begin{tabular}{|c|c|c|c|}
\hline & No Pork & Agg. Pork & Disagg. Pork \\
\hline $\begin{array}{l}\text { Aggregate Pork Spending } \\
\text { (in millions of \$) }\end{array}$ & & $\begin{array}{l}0.459^{* * *} \\
(0.104)\end{array}$ & \\
\hline $\begin{array}{l}\text { Pork in Final Year } \\
\text { (in millions of \$) }\end{array}$ & & & $\begin{array}{l}0.068^{* * *} \\
(0.019)\end{array}$ \\
\hline $\begin{array}{l}\text { Pork in Penultimate Year } \\
\text { (in millions of \$) }\end{array}$ & & & $\begin{array}{l}0.099 * * * \\
(0.019)\end{array}$ \\
\hline LQ Manufacturing & $\begin{array}{l}12.68 \\
(13.49)\end{array}$ & $\begin{array}{l}19.10 \\
(12.61)\end{array}$ & $\begin{array}{l}17.16 \\
(0.019)\end{array}$ \\
\hline LQ FIRE & $\begin{array}{l}13.04 \\
(26.04)\end{array}$ & $\begin{array}{l}31.49 \\
(24.84)\end{array}$ & $\begin{array}{l}22.04 \\
(24.32)\end{array}$ \\
\hline Percent under 18 & $\begin{array}{l}5.174^{* *} \\
(2.128)\end{array}$ & $\begin{array}{l}2.803 \\
(2.121)\end{array}$ & $\begin{array}{l}1.799 \\
(2.162)\end{array}$ \\
\hline Percent over 65 & $\begin{array}{l}0.427 \\
(0.819)\end{array}$ & $\begin{array}{l}0.167 \\
(0.815)\end{array}$ & $\begin{array}{l}0.214 \\
(0.797)\end{array}$ \\
\hline Percent Black & $\begin{array}{l}0.767 * * * \\
(0.256)\end{array}$ & $\begin{array}{l}0.575^{* *} \\
(0.257)\end{array}$ & $\begin{array}{l}0.611^{* *} \\
(0.249)\end{array}$ \\
\hline Percent Bachelor's & $\begin{array}{l}5.602 * * * \\
(1.596)\end{array}$ & $\begin{array}{l}5.800^{* * *} \\
(1.491)\end{array}$ & $\begin{array}{l}4.951 * * * \\
(1.149)\end{array}$ \\
\hline $\begin{array}{l}\text { Average Wage } \\
\text { (thousands of } \$ \text { ) }\end{array}$ & $\begin{array}{l}-0.004 * * * \\
(0.0009)\end{array}$ & $\begin{array}{l}-0.004 * * * \\
(0.001)\end{array}$ & $\begin{array}{l}-0.003^{* * *} \\
(0.001)\end{array}$ \\
\hline Right to Work & $\begin{array}{l}-39.77^{* * *} \\
(14.43)\end{array}$ & $\begin{array}{l}-19.46 \\
(13.62)\end{array}$ & $\begin{array}{l}-17.22 \\
(13.42)\end{array}$ \\
\hline Interstate Miles & $\begin{array}{l}0.098^{* * * *} \\
(0.017)\end{array}$ & $\begin{array}{l}0.079 * * * \\
(0.157)\end{array}$ & $\begin{array}{l}0.082 * * * \\
(0.015)\end{array}$ \\
\hline July Temperature & $\begin{array}{l}1.185^{*} \\
(1.159)\end{array}$ & $\begin{array}{l}1.461 \\
(1.040)\end{array}$ & $\begin{array}{l}1.305 \\
(1.035)\end{array}$ \\
\hline 'Extra' Election & $\begin{array}{l}2.158 \\
(3.344)\end{array}$ & $\begin{array}{l}3.566 \\
(3.353)\end{array}$ & $\begin{array}{l}1.165 \\
(3.385)\end{array}$ \\
\hline Number of Observations & 300 & 300 & 300 \\
\hline Number of Panels & 6 & 6 & 6 \\
\hline$R^{2}$ & 0.275 & 0.434 & 0.472 \\
\hline$F$-statistic & $100.84 * * *$ & $126.91 * * *$ & $143.17 * * *$ \\
\hline
\end{tabular}

In column 3 of Table 4, I replace the aggregated pork-barrel spending variable with the two prior years of pork-barrel spending. In this case, the $\$ 1$ million worth of pork-barrel spending appropriated in the final two years of the period increases GDP by $\$ 167,000$. As mentioned earlier, states are generally required to fund a certain percentage of a project funded by pork-barrel money. Therefore, even though there is evidence that pork-barrel spending increases economic activity 
within a state, it is possible that at least some of that activity is caused by the additional state spending.

\subsection{Three-Year Moving Average Estimates of State Employment Effects}

For the sake of robustness, I repeat the total employment and GDP regressions using a three-year moving average approach. This approach moderates the data by taking the average of the three years surrounding the year being examined. The effects of any shocks are minimized by taking a three-year moving average. The results for the change in total employment regressions are given in Table 5. Overall, these results are very similar to the panel estimates. The one big

Table 5: Moving Average Total Employment Regressions, 2001-2011

\begin{tabular}{|c|c|c|c|}
\hline & No Pork & Agg. Pork & Disagg. Pork \\
\hline $\begin{array}{l}\text { Aggregate Pork Spending } \\
\text { (in millions of } \$ \text { ) }\end{array}$ & & $\begin{array}{c}31.60 \\
(32.93)\end{array}$ & \\
\hline $\begin{array}{l}\text { Pork in Final Year } \\
\text { (in millions of } \$ \text { ) }\end{array}$ & & & $\begin{array}{l}1,505 * * * \\
(312.25)\end{array}$ \\
\hline $\begin{array}{l}\text { Pork in Penultimate Year } \\
\text { (in millions of } \$ \text { ) }\end{array}$ & & & $\begin{array}{c}-1,482 * * * \\
(305.64)\end{array}$ \\
\hline LQ Manufacturing & $\begin{array}{l}-479.09 \\
(30,332)\end{array}$ & $\begin{array}{c}8,914 \\
(31,876)\end{array}$ & $\begin{array}{l}-10,831 \\
(30,491)\end{array}$ \\
\hline LQ FIRE & $\begin{array}{c}7,667.5 \\
(99,709)\end{array}$ & $\begin{array}{c}36,778 \\
(104,235)\end{array}$ & $\begin{array}{c}5,021 \\
(100,057)\end{array}$ \\
\hline Percent under 18 & $\begin{array}{c}-29,315 * * * \\
(9,596)\end{array}$ & $\begin{array}{c}-31,223 * * * \\
(9,801)\end{array}$ & $\begin{array}{c}-26,332 * * * \\
(9,616)\end{array}$ \\
\hline Percent over 65 & $\begin{array}{l}-2,772 \\
(6,667)\end{array}$ & $\begin{array}{l}-3,495 \\
(6,708)\end{array}$ & $\begin{array}{l}-3,122 \\
(6,504)\end{array}$ \\
\hline Percent Black & $\begin{array}{l}-4,798 * * * \\
(1,620)\end{array}$ & $\begin{array}{c}-5,318 * * * \\
(1,709)\end{array}$ & $\begin{array}{l}-4,383 * * * \\
(1,661)\end{array}$ \\
\hline Percent Bachelor's & $\begin{array}{c}-9,414 * * \\
(4,446)\end{array}$ & $\begin{array}{l}-7,868 * \\
(4,730)\end{array}$ & $\begin{array}{l}-8,110^{*} \\
(4,471)\end{array}$ \\
\hline $\begin{array}{l}\text { Average Wage } \\
\text { (thousands of } \$ \text { ) }\end{array}$ & $\begin{array}{c}23.68 * * * \\
(3.272)\end{array}$ & $\begin{array}{c}22.62 * * * \\
(3.456)\end{array}$ & $\begin{array}{c}20.62 * * * \\
(3.322)\end{array}$ \\
\hline Right to Work & $\begin{array}{c}131,298 * * * \\
(36,069)\end{array}$ & $\begin{array}{c}145,596 * * * \\
(39,029)\end{array}$ & $\begin{array}{c}112,840 * * * \\
(38,166)\end{array}$ \\
\hline Interstate Miles & $\begin{array}{c}154.02 * * * \\
(42.173)\end{array}$ & $\begin{array}{c}142.88 * * * \\
(43.75)\end{array}$ & $\begin{array}{l}150.80 * * * \\
(41.99)\end{array}$ \\
\hline July Temperature & $\begin{array}{c}3,332 \\
(2,763)\end{array}$ & $\begin{array}{c}3,609 \\
(2,779)\end{array}$ & $\begin{array}{c}3,229 \\
(2,669)\end{array}$ \\
\hline Number of Observations & 300 & 300 & 300 \\
\hline $\begin{array}{l}R^{2} \\
F \text {-statistic }\end{array}$ & $\begin{array}{c}0.248 \\
9.54 * * *\end{array}$ & $\begin{array}{c}0.251 \\
8.76 * * *\end{array}$ & $\begin{array}{c}0.308 \\
10.67 * * *\end{array}$ \\
\hline
\end{tabular}

Notes: Standard error in parentheses: $* * *=1$ percent, $* *=5$ percent, $*=10$ percent significance level

difference is that the magnitude of the pork-barrel spending variable is larger. Specifically, the three-year moving average approach shows that a $\$ 1$ million increase in pork-barrel spending in the final year of a five-year period increases employment by a little more than 1,500 jobs with 
approximately 1,480 jobs being lost the following year. While the magnitude of the values does differ to some degree from the previous employment estimates, the same pattern is present. Specifically, an influx of federal appropriations increases employment in the year in which the money is received, yet most of the jobs are lost in subsequent years. This is further evidence of the lack of long-term economic benefits produced by this type of federal spending.

Table 6: Moving Average State's Gross Product Regressions, 2001-2011

\begin{tabular}{|c|c|c|c|}
\hline $\begin{array}{l}\text { Aggregate Pork Spending } \\
\text { (in millions of \$) }\end{array}$ & No Pork & $\begin{array}{c}\text { Agg. Pork } \\
0.269^{* * *} \\
(0.003)\end{array}$ & Disagg. Pork \\
\hline $\begin{array}{l}\text { Pork in Final Year } \\
\text { (in millions of \$) }\end{array}$ & & & $\begin{array}{c}0.024 \\
(0.035)\end{array}$ \\
\hline $\begin{array}{l}\text { Pork in Penultimate Year } \\
\text { (in millions of \$) }\end{array}$ & & & $\begin{array}{c}0.116^{* * *} \\
(0.034)\end{array}$ \\
\hline LQ Manufacturing & $\begin{array}{c}5.167 \\
(3.379)\end{array}$ & $\begin{array}{c}13.16^{* * * *} \\
(3.208)\end{array}$ & $\begin{array}{c}13.88 * * * \\
(3.17)\end{array}$ \\
\hline LQ FIRE & $\begin{array}{c}-3.427 \\
(11.107)\end{array}$ & $\begin{array}{l}21.37 * * \\
(10.49)\end{array}$ & $\begin{array}{r}23.11^{* *} \\
(10.18)\end{array}$ \\
\hline Percent under 18 & $\begin{array}{l}2.154^{* *} \\
(1.069)\end{array}$ & $\begin{array}{c}0.529 \\
(0.986)\end{array}$ & $\begin{array}{l}-0.172 \\
(0.979)\end{array}$ \\
\hline Percent over 65 & $\begin{array}{l}1.473 * * \\
(0.743)\end{array}$ & $\begin{array}{c}0.858 \\
(0.675)\end{array}$ & $\begin{array}{c}0.657 \\
(0.661)\end{array}$ \\
\hline Percent Black & $\begin{array}{l}0.455^{* *} \\
(0.181)\end{array}$ & $\begin{array}{c}0.012 \\
(0.172)\end{array}$ & $\begin{array}{l}-0.066 \\
(0.169)\end{array}$ \\
\hline Percent Bachelor's & $\begin{array}{l}1.146^{* *} \\
(0.495)\end{array}$ & $\begin{array}{c}2.463^{* * *} \\
(0.476)\end{array}$ & $\begin{array}{c}2.363 * * * \\
(0.455)\end{array}$ \\
\hline $\begin{array}{l}\text { Average Wage } \\
\text { (thousands of } \$ \text { ) }\end{array}$ & $\begin{array}{l}0.001^{* *} \\
(0.0003)\end{array}$ & $\begin{array}{r}-0.00005 \\
(0.0003)\end{array}$ & $\begin{array}{c}0.0002 \\
(0.0003)\end{array}$ \\
\hline Right to Work & $\begin{array}{c}-9.241 * * \\
(4.018)\end{array}$ & $\begin{array}{c}2.939 \\
(3.928)\end{array}$ & $\begin{array}{c}5.644 \\
(3.389)\end{array}$ \\
\hline Interstate Miles & $\begin{array}{c}0.048^{* * *} \\
(0.005)\end{array}$ & $\begin{array}{c}0.040^{* * *} \\
(0.004)\end{array}$ & $\begin{array}{c}0.039^{* * *} \\
(0.004)\end{array}$ \\
\hline July Temperature & $\begin{array}{c}0.293 \\
(0.308)\end{array}$ & $\begin{array}{l}0.529^{*} \\
(0.280)\end{array}$ & $\begin{array}{l}0.523^{*} \\
(0.272)\end{array}$ \\
\hline $\begin{array}{l}\text { Number of Observations } \\
R^{2} \\
F \text {-statistic }\end{array}$ & $\begin{array}{c}300 \\
0.411 \\
20.15^{* * *}\end{array}$ & $\begin{array}{c}300 \\
0.521 \\
28.44 * * *\end{array}$ & $\begin{array}{c}300 \\
0.547 \\
28.91 * * *\end{array}$ \\
\hline
\end{tabular}

Notes: Standard error in parentheses: $* * *=1$ percent, $* *=5$ percent, $*=10$ percent significance level

\subsection{Three-Year Moving Average Estimates of State Economic Growth Rates}

To further show the robustness of my results, I repeat the GDP regressions using the three-year moving average approach. The results are given in Table 6 . Again, the results are very similar to the previous section and show that a $\$ 1$ million increase in pork-barrel appropriations does increase GDP by more than $\$ 1$ million. 


\subsection{Spatial Estimates of State Employment Effects}

Because labor markets tend to be regional, a state-by-state approach is likely to yield biased estimates of the effects of targeted expenditures. Specifically, pork-barrel projects in one state may have an impact on employment in neighboring states. This is especially likely when projects are close to a state border. To test for such effects, two additional series of estimates were undertaken using a spatial framework inspired by the non-spatial Blumenthal, Wolman, and Hill (2009) model, the change in the total employment level in the state is estimated using the spatial lag model (SLX):

$$
\Delta \text { Total Employment }{ }_{i t}=\operatorname{pork}_{i t} \beta_{1}+\operatorname{pork}_{i, t-1} \beta_{1}+X_{i t} \beta_{k}+W_{p o r k} \theta+\varepsilon_{i t}
$$

where $X_{i t}$ is the set of independent variables in state $i$, pork $_{i t}$ and pork $k_{i, t-t}$ arethe current and lagged pork-barrel spending $\beta$ and $\theta$ are fixed, but unknown coefficients, $W$ por $k_{i}$ is the spatially lagged pork-barrel spending term, $W$ is the five-nearest neighbor weight matrix and $\varepsilon$ is the error term. Table 7 shows the results for the employment estimate using this spatial approach.

As we can see in Table 7, the results that account for the spatial component are similar to the results that do not use spatial methods. A $\$ 1$ million increase in pork-barrel spending increases employment in the state which acquired the pork-barrel funding by approximately 1,100 jobs. But, pork-barrel spending funneled to neighboring states can actually have a negative impact on employment, likely due to backwash effects. The other independent variables are also robust when using the spatial model. While spillover effects are likely, they mainly occur on the borders. For example, Montana's five-nearest neighbors are Washington, Idaho, Wyoming, South Dakota, and North Dakota. These six states have a total area of approximately 548,000 square miles (or 18 percent of the total area of the U.S.). It is highly unlikely that there is a significant amount of interstate commuting between these six states. On the other hand, Rhode Island's five-nearest neighbors only account for 73,000 square miles. Employment spillovers are much more likely in this region.

\subsection{Spatial Estimates of State Employment Effects}

Table 8 displays the results for the spatial change in GDP. Unlike the employment estimates, there is some evidence of spatial spillovers. Specifically, there appears to be a backwash effect as an increase in neighboring states' appropriations of pork-barrel spending may lead to a decrease in GDP for the state of interest. Again, the other independent variables are similar to those in the original model.

\subsection{Implications of Estimates}

The above results provide support for the hypothesis that earmarked and other targeted spending can be used to increase employment. The results also suggest that the jobs created through these programs are temporary. While this may seem like a downside of pork-barrel spending, it actually provides advantages for incumbents. Because these jobs eventually disappear, the incumbent must continue to secure money to bring in new jobs. This benefits the incumbent because it allows him/her to continually attach his/her name to job-creating legislation. A legislator may have a difficult time taking credit for maintaining employment levels but may have a much easier time taking credit for jobs created using pork-barrel spending. 
Table 7: Spatial Change in Employment Regressions, 2001-2011

\begin{tabular}{|c|c|c|}
\hline & Agg. Pork & Disagg. Pork \\
\hline $\begin{array}{l}\text { Aggregate Pork Spending } \\
\text { (in millions of \$) }\end{array}$ & $\begin{array}{c}51.706 \\
(66.052)\end{array}$ & \\
\hline $\begin{array}{l}\text { Pork in Final Year } \\
\text { (in millions of } \$ \text { ) }\end{array}$ & & $\begin{array}{l}1,155.31 * * * \\
\quad(260.30)\end{array}$ \\
\hline $\begin{array}{l}\text { Pork in Penultimate Year } \\
\text { (in millions of } \$ \text { ) }\end{array}$ & & $\begin{array}{l}-972.36 * * * \\
(258.48)\end{array}$ \\
\hline $\begin{array}{l}\text { SLX Aggregate Pork Spending } \\
\text { (in millions of } \$ \text { ) }\end{array}$ & $\begin{array}{c}84.563 \\
(130.65)\end{array}$ & \\
\hline $\begin{array}{l}\text { SLX Pork in Final Year } \\
\text { (in millions of } \$ \text { ) }\end{array}$ & & $\begin{array}{c}-789.49 * * \\
(394.30)\end{array}$ \\
\hline $\begin{array}{l}\text { SLX Pork in Penultimate Year } \\
\text { (in millions of } \$ \text { ) }\end{array}$ & & $\begin{array}{c}171.33 \\
(397.31)\end{array}$ \\
\hline LQ Manufacturing & $\begin{array}{l}-36,779 \\
(76,300)\end{array}$ & $\begin{array}{l}-59,899 \\
(72,661)\end{array}$ \\
\hline LQ FIRE & $\begin{array}{l}4,768.26 \\
(172,214)\end{array}$ & $\begin{array}{l}-101,562 \\
(158,636)\end{array}$ \\
\hline Percent under 18 & $\begin{array}{c}-62,364 * * * \\
(16,915)\end{array}$ & $\begin{array}{c}-44,911 * * * \\
(16,905)\end{array}$ \\
\hline Percent over 65 & $\begin{array}{c}-8,089 \\
(10,386)\end{array}$ & $\begin{array}{c}-1,620.89 \\
(10,014)\end{array}$ \\
\hline Percent Black & $\begin{array}{c}-9,928 * * * \\
(2,734)\end{array}$ & $\begin{array}{l}-8,905.45 * * * \\
\quad(2,589.35)\end{array}$ \\
\hline Percent Bachelor's & $\begin{array}{c}-6,781.38 \\
(9,467)\end{array}$ & $\begin{array}{c}-14,259^{*} \\
(8,935)\end{array}$ \\
\hline $\begin{array}{l}\text { Average Wage } \\
\text { (thousands of } \$ \text { ) }\end{array}$ & $\begin{array}{l}38.99 * * * \\
(7.243)\end{array}$ & $\begin{array}{l}42.81 * * * \\
(6.75)\end{array}$ \\
\hline Right to Work & $\begin{array}{c}277,005 * * * \\
(71,458)\end{array}$ & $\begin{array}{l}225,226 * * * \\
(68,406)\end{array}$ \\
\hline Interstate Miles & $\begin{array}{l}316.16 * * * \\
(85.72)\end{array}$ & $\begin{array}{l}281.51 * * * \\
\quad(81.24)\end{array}$ \\
\hline July Temperature & $\begin{array}{c}8,177.51 \\
(5,251.23) \\
\end{array}$ & $\begin{array}{l}8,959.91 * \\
(5,027.01)\end{array}$ \\
\hline Number of Observations & 300 & 300 \\
\hline$R^{2}$ & 0.255 & 0.319 \\
\hline$F$-statistic & $8.17 * * *$ & $9.54 * * *$ \\
\hline
\end{tabular}

These types of programs do not appear to be an economically efficient strategy for creating and sustaining economic growth. When all of the costs, such as administrative costs, compliance costs, and rent-seeking costs, of pork-barrel spending are included, it seems as though pork-barrel spending may not be a viable long-term economic growth strategy. Instead, as has been stated in this paper and the previous literature, pork-barrel spending is used nearly exclusively for short-

(C) Southern Regional Science Association 2016. 
Table 8: Spatial Change in GDP Results

\begin{tabular}{|c|c|c|}
\hline $\begin{array}{l}\text { Aggregate Pork Spending } \\
\text { (in millions of \$) }\end{array}$ & $\begin{array}{c}\text { Aggregated Pork } \\
0.5569^{* * *} \\
(0.0065)\end{array}$ & Disaggregated Pork \\
\hline $\begin{array}{l}\text { Pork in Final Year } \\
\text { (in millions of } \$ \text { ) }\end{array}$ & & $\begin{array}{c}0.076^{* * *} \\
(0.028)\end{array}$ \\
\hline $\begin{array}{l}\text { Pork in Penultimate Year } \\
\text { (in millions of \$) }\end{array}$ & & $\begin{array}{c}0.130 * * * \\
(0.027)\end{array}$ \\
\hline $\begin{array}{l}\text { SLX Aggregate Pork Spending } \\
\text { (in millions of } \$ \text { ) }\end{array}$ & $\begin{array}{c}-0.442 * * * \\
(0.0129)\end{array}$ & \\
\hline $\begin{array}{l}\text { SLX Pork in Final Year } \\
\text { (in millions of } \$ \text { ) }\end{array}$ & & $\begin{array}{c}-0.104 * * \\
(0.042)\end{array}$ \\
\hline $\begin{array}{l}\text { SLX Pork in Penultimate Year } \\
\text { (in millions of } \$ \text { ) }\end{array}$ & & $\begin{array}{l}-0.048 \\
(0.043)\end{array}$ \\
\hline LQ Manufacturing & $\begin{array}{l}17.608 * * \\
(7.544)\end{array}$ & $\begin{array}{c}14.329 * \\
(7.76)\end{array}$ \\
\hline LQ FIRE & $\begin{array}{c}37.688 * * \\
(17.062)\end{array}$ & $\begin{array}{l}30.49^{*} \\
(16.98)\end{array}$ \\
\hline Percent under 18 & $\begin{array}{c}1.213 \\
(1.672)\end{array}$ & $\begin{array}{c}0.657 \\
(1.809)\end{array}$ \\
\hline Percent over 65 & $\begin{array}{c}0.727 \\
(1.027)\end{array}$ & $\begin{array}{c}0.866 \\
(1.072)\end{array}$ \\
\hline Percent Black & $\begin{array}{l}0.647 * * \\
(0.270)\end{array}$ & $\begin{array}{l}0.656^{*} \\
(0.277)\end{array}$ \\
\hline Percent Bachelor's & $\begin{array}{l}2.417 * * \\
(0.936)\end{array}$ & $\begin{array}{l}2.165 * \\
(0.956)\end{array}$ \\
\hline $\begin{array}{l}\text { Average Wage } \\
\text { (thousands of } \$ \text { ) }\end{array}$ & $\begin{array}{c}0.0006 \\
(0.0007)\end{array}$ & $\begin{array}{c}0.001 \\
(0.0007)\end{array}$ \\
\hline Right to Work & $\begin{array}{c}2.177 \\
(7.065)\end{array}$ & $\begin{array}{l}-1.298 \\
(7.321)\end{array}$ \\
\hline Interstate Miles & $\begin{array}{c}0.0625 * * * \\
(0.0084)\end{array}$ & $\begin{array}{l}0.072 * * * \\
(0.009)\end{array}$ \\
\hline July Temperature & $\begin{array}{l}0.7556 \\
(0.519) \\
\end{array}$ & $\begin{array}{c}0.665 \\
(0.537)\end{array}$ \\
\hline Number of Observations & 300 & 300 \\
\hline Number of Panels & 6 & 6 \\
\hline R-squared & 0.559 & 0.528 \\
\hline F-Statistic & $30.33 * * *$ & $22.78 * * *$ \\
\hline
\end{tabular}

term political benefits (Stratmann, 2013; Levitt and Snyder, 1997; Bickers and Stein, 1996). Further, because electoral cycles are so short, there is a near continuous incentive to engage in this type of spending. 


\section{CONCLUSIONS}

This paper provides evidence that earmarked and other targeted spending has local economic effects on employment and economic development, albeit temporary. By using the model established by Blumenthal, Wolman, and Hill (2009), I modeled the factors which influenced changes in total employment and changes in GDP between in a variety of time periods between 2001 and 2011. The main addition to the model was the inclusion of a pork-barrel spending variable. When an aggregated pork-barrel spending variable is used, no statistically significant effect was found. However, when lagged pork-barrel spending is used, an additional $\$ 1$ million dollars of pork-barrel spending increased employment by more than 900 jobs, but most of those jobs disappeared after only one year. This is likely due to the prominence of construction and construction-related jobs created through these types of programs. Jobs which did remain after the first two years tended to disappear within five years of the original funding. Similarly, GDP did seem to increase in excess of the size of the federal subsidy though it is possible that some of this increase is due to the matching funds a state is required to contribute to the federal projects.

When a spatial lag model (SLX) is used, there is evidence that pork-barrel spending yields backwash effects as an increase in pork-barrel spending in one state leads to a decrease in employment in neighboring states. The results mirror the non-spatial regressions, which indicate a quick increase in employment followed by a reduction only a few years later. This gives evidence to the belief that pork-barrel spending generates only spatially concentrated benefits. Specifically, pork-barrel spending is only used to benefit a legislator's state without any regard to the costs borne by the other states (and the rest of the world).

Ultimately, there is evidence that pork-barrel spending can be used for countercyclical policies but not for promoting long-term economic growth or reducing unemployment in the longterm. The fact that such programs are adopted in good times and bad suggests that pork-barrel spending is utilized by politicians for short-term gains in hopes of increasing their chances of being reelected, rather than to promote long-term economic objectives. Therefore, while there may be short-term economic and political benefits, there are not long-term economic benefits.

While this paper focuses on employment and economic growth, it should be noted that there are other benefits to the use of pork-barrel spending. For example, pork-barrel spending that funds a new museum or a new highway may marginally increase the employment level in an area after it is built, but the main purpose of the museum is to provide an amenity for state residents and the main purpose of the highway is to reduce the number of deaths and accidents on the existing highway. Whether the employment effects or the amenity effects of targeted expenditures have the greater effect on incumbent reelection prospects is left for future work.

\section{REFERENCES}

Alt, James E. (1985) "Political Parties, World Demand, and Unemployment: Domestic and International Sources of Economic Activity,“ American Political Science Review, 79, $1016-1040$.

Bickers, Kenneth N. and Robert M. Stein. (1996) "The Electoral Dynamics of the Federal Pork Barrel," American Journal of Political Science, 40, 1300-1326.

Blumenthal, Pamela, Harold L. Wolman, and Edward Hill. (2009) "Understanding the Economic Performance of Metropolitan Areas in the United States," Urban Studies, 46, 605-627.

(C) Southern Regional Science Association 2016. 
Blundell, Richard, Lorraine Dearden, Costas Meghir, and Barbara Sianesi. (1999) "Human Capital Investment: The Returns from Education and Training to the Individual, the Firm and the Economy," Fiscal Studies, 20, 1-23.

Bondonio, Daniele and John Engberg. (2000) "Enterprise Zpmes and Local Employment: Evidence from the States' Programs," Regional Science and Urban Ecomomics, 30, 519549.

Boyle, Melissa and Victor Matheson. (2009) "Determinants of the Distribution of Congressional Earmarks across States," Economic Letters, 104, 63-65.

Card, David. (1999) "The Casual Effect of Education on Earnings," Handbook of Labor Economics, 3, 1801-1863.

Faulk, Dagney. (2002) "Do State Economic Development Incentives Create Jobs? An Analysis of State Employment Tax Credits," National Tax Journal, 55, 263-280.

Ferejohn, John A. and Keith Krehbiel. (1987) "The Budget Process and the Size of the Budget," American Journal of Political Science, 296-320.

Glaeser, Edward, Heidi D. Kallal, José Scheinkman, and Andrei Shleifer. (1992) "Growth in Cities," Journal of Political Economy, 100, 733-746.

Glaeser, Edward, José Scheinkman, and Andrei Shleifer. (1995) "Economic Growth in a Crosssection of Cities," Journal of Monetary Economics, 36, 117-144.

Glaeser, Edward and Jesse M. Shapiro. (2001) "Is There a New Urbanism? The Growth of U.S. Cities in the 1990's," National Bureau of Economic Research Working Paper 8357: Cambridge, MA.

Gramlich, Edward M. (1987) "Federalism and Federal Deficit Reduction," National Tax Journal, 40, 299-313.

Gwartney, James D. and Robert Lawson. (1996) Economic Freedom of the World: 1996 Annual Report. Fraser Institute: Vancouver.

Hanson, Andrew. (2009) "Local Employment, Poverty, and Property Value Effects of Geographically-Targeted Tax Incentives: An Intstrumental Variables Approach," Regional Science and Urban Economics, 39, 721-731.

Henderson, J. Vernon, Ari Kuncoro, and Matthew Turner. (1995) "Industrial Development in Cities," Journal of Political Economy, 103, 1067-1090.

Hines, James R. and Richard H. Thaler. (1995) "Anomalies: The Flypaper Effect," Journal of Economic Perspectives, 9, 217-226.

Holmes, Thomas J. (1998) "The Effect of State Policies on the Location of Manufacturing: Evidence from State Borders," Journal of Political Economy, 106, 667-705.

Inman, Robert P. (1988) "Federal Assistance and Local Services in the United States: The Evolution of a New Federalist Fiscal Order," Fiscal Federalism: Quantitative Studies, 3378.

. (2008) "The Flypaper Effect," National Bureau of Economic Research Working Paper 14579: Cambridge, MA.

(C) Southern Regional Science Association 2016. 
Karabegović, Amela, Fred McMahon, and Dexter Samida. (2002) Economic Freedom of North America. Fraser Institute: Vancouver.

Keefer, Philip and Stuti Khemani. (2009) "When Do Legislators Pass on Pork? The Role of Political Parties in Determinating Legislator Effort," American Political Science Review, 103, 99-112.

Leduc, Sylvain and Daniel Wilson. (2015) "Are State Governments Roadblocks to Federal Stimulus? Evidence on the Flypaper Effect of Highway Grants in the 2009 Recovery Act," Federal Reserve Bank of San Francisco Working Paper 2013-16: San Francisco.

Levy, Alice, Robert Darst, Hal Wolman, and Garry Young. (2008) "Literature Review on the Determinants of Residential Employment," George Washington Institute of Public Policy Working Paper 033: Washington, DC.

Miller, Terry, Kim R. Holmes, Edwin J. Feulner, Paul A. Gigot, Anthony B. Kim, Bryann Riley, James M. Roberts, J.D. Foster, Nahid Kalbasi Anaraki and Obiageli Ezekwesili. (2012) 2012 Index of Economic Freedom. The Heritage Foundation: Washington, DC.

Munnell, Alicia. (1992) "Policy Watch: Infrastructure Investment and Economic Growth," The Journal of Economic Perspectives, 6, 189-198.

Munnell, Alicia and Leah Cook. (1990) "How Does Public Infrastructure Affect Regional Economic Performance?," New England Economic Review, September/October, 11-33.

Neumark, David. (2012) "Spurring Job Creation in Response to Severe Recessions: Reconsidering Hiring Credits," Journal of Policy Analysis and Management, 32, 142-171

Nickell, Stephen. (1997) "Unemployment and Labor Market Rigidities: Europe versus North America," The Journal of Economic Perspectives, 11, 55-74.

. (2004) "Employment and Taxes," Centre for Economic Performance Discussion Paper 634. CESifo Group: Munich.

Nickell, Stephen and Richard Layard. (1999) "Labor Market Institutions and Economic Performance," in Handbook of Labor Economics, edited by David Card and Orley Ashenfelter, 3029-3084. Elsevier: London, UK.

Rephann, Terance and Andrew Isserman. (1994) "New highways as Economic Development Tools: An Evaluation using Quasi-experimental Matching Methods.” Regional Science and Urban Economics, 24, 723-751.

Saks, Raven E. (2008) "Job Creation and Housing Construction: Constraints on Metropolitan Area Employment Growth," Journal of Urban Economics, 64, 178-195.

Sanchez, Thomas W. (1999) "The Connection Between Public Transit and Employment: The Cases of Portland and Atlanta," Journal of the American Planning Association, 65, 284296.

Schultz, Theodore W. (1961) "Investment in Human Capital," The American Economic Review, $51,1-17$.

Scovel III, Calvin L. (2007) Review of Congress Earmarks Within Department of Transportation Funds. Department of Transportation: Washington, DC.

(C) Southern Regional Science Association 2016. 
Shepsle, Kenneth. A., Eric S. Dickson, Robert P. Van Houweling. (2002) "Bargaining in Legislatures with Overlapping Generation of Politicians." Paper presented at the Annual Meeting of the American Political Science Association: Washington, DC.

Shepsle, Kenneth. A. and Barry R. Weingast. (1981) "Structure-induced Equilibrium and Legislative Choice," Public Choice, 37, 503-519.

Smith, James P. and Finis R. Welch. (1989) "Black Economic Progress after Myrdal," Journal of Economic Literature, 27, 519-564.

Stansel, Dean. B. (2013) “An Economic Freedom Index for U.S. Metropolitan Areas,” Journal of Regional Analysis and Policy, 43, 3-20.

Stein, Robert M. and Kenneth N. Bickers. (1997) Perpetuating the Pork Barrel: Policy Subsystems and American Demoncracy. Cambridge University Press: Cambridge, UK.

Stratmann, Thomas. (2013) "The Effects of Earmarks on the Likelihood of Reelection," European Journal of Political Economy, 32, 341-355.

United Nations. (2007) Report on the World Social Situation 2007: The Employment Imperative. Department of Economic and Social Affairs of the United Nations Secretariat: New York.

Vega, Solmaria Halleck and J. Paul Elhorst. (2015) "The SLX Model," Journal of Regional Science, 55, 339-363.

Weingast, Barry R. (1979) "A Rational Choice Perspective on Congressional Norms," American Journal of Political Science, 23, 245-262.

Weingast, Barry R., Kenneth A. Shepsle, and Christopher Johnsen. (1981) "The Political Economy of Benefits and Costs: A Neoclassical Approach to Distributive Politics," Journal of Political Economy, 89, 642-664.

Wolman, Harold, Alice Levy, Garry Young, and Pamela Blumenthal. (2008) "Economic Competitiveness and the Determinants of Sub-National Area Economic Activity," George Washington Institute of Public Policy: Washington, DC.

Zavodny, Madeline. (2000) “The Effect of Minimum Wage on Employment and Hours," Labour Economics, 7, 729-750.

(c) Southern Regional Science Association 2016. 